\title{
Administração de Projetos de Assistência Técnica
}

\author{
Evangelos John Rizos \\ Consultor da OMS na Malásia \\ Tradução de Maria de Lourdes L. Moviano
}

N

ESTES últ mos dez anos a assistência técnica espalhou-se por todos os recantos do mundo. Foi um periodo de prolunda evolução, que atingiu tradicionais e enraizados métodos de realização. Hoje, nenhum pais permanece alhe o ao desenvolvimento e ninguém se deixa ficar congelado no passado. O mundo contempo. râneo está dominado pela crescente necessidade de resolver os problemas acumulados que lhe legou o passado. A arrancada para a independência e o autogovêrno deram aos homens a satisfação e a responsabilidade de tomarem decisões. $E$ as situações que têm a resolver são inéditas e complexas. A necessidade de encontrar soluções realistas focaliza a atenção na necessidade de ação positiva nos mais variados assuntos. Nos anos vindouros, a assistência técnica certamente ampliar-se-á qualitativa e quant tativamente. A necessidade nunca foi mais premente.

Neste trabalho, trataremos dos vários projetos de assistência técnica e da respectiva administração. Mais especificamente, trataremos dos projetos individuais, seja qual fôr seu conteúdo, do programa multinacional de assistência técnica realizado pelas $\mathrm{Na}$ ções Unidas e por suas agências especializadas aqui denominadas "Organização Internacional". O projeto é o principal veiculo do programa de assistência técnica. Seu campo de atividade específ:ca pode ser agricultura, educação, saúde, administração pública ou outro qualquer setor dentro da estrutura geral de estimulo ao desenvolvimento econômico e social de determinado país.

De inicio, talvez convenha formular uma pergunta - Valerá a pena identificar a administração de projetos de assistência técnica como algo distinto, que mereça atenção especial? A resposta é afirmativa. Se os objetivos que o técnico (aqui referido como "encarregado do projeto") procura, são importantes e se os meios que usa são frutiferos, justifica-se uma análise atenta do processo de administração adotado. O encarregado do projeto não pode 
atingir as metas de modo irrefletido, frio ou automático. No esfôrço de alcançar os objetivos visados, a linha de ação adotada não pode ser instintiva nem de caráter rotineiro. Convém notar que restringir nosso interêsse a um projeto de assistência técnica é focalizar a atenção nos objetivos a serem alcançados e, aceitar sua administração, é introduzir os meios de realização e influência dêstes nos objetivos desejados. Objectivos e administração são elementos correlatos. São têrmos que não se traduzem em dicotomia, mas numa diferença de época. Os "objetivos" do projeto são uma série de atos considerados num estágio remoto e "administração" é apenas a série considerada num estágio anterior.

A administração bem sucedida de um projeto de assistência técnica num país estrangeiro é diverso do desempenho bem sucedido do encarregado do projeto em trabalho realizado em sua terra. Exige uma capacidade diferente da competência em determinado setor em seu próprio pais. Os problemas são inéditos e, em sua sutileza, apresentam inúmeras incógnitas. Pressões e atritos são quase inevitáveis, particularmente quando as fôrç̣ds culturais $e$ os valôres que influem nas politicas, atitudes e praxes do país anfitrião são mal compreendidas ou mal interpretadas. O que passaremos a expor representa um esfôrço no sentido de esclarecer hábitos familiares e sugerir um ponto-de-vista que talvez possa habilitar o encarregado do projeto a apreender os fatôres que terá de ponderar, dar-lhe certo senso de proporção, ajudá-lo a apreciar e talvez avaliar as circunstâncias condicionantes e, finalmente, dar-lhe uma ampla perspectiva de seu trabalho. Não é nosso intento oferecer determinada fórmula, dar a receita do êxito, nem mesmo propor normas ou "a única modalidade" adequada, porque nenhuma se aplicará a todos os casos. Quando se enfrentam problemas nos quais têm importante papel instituições humanas e sistemas de valôres, representando elemento inerente à situação geral, o melhor é nada prometer. De fato, cada projeto por si corresponde a uma nova situação, exigindo compreensão imaginativa, como preliminar para um bom julgamento e como base para ação. Cada projeto difere de todos os demais porque, da mesma forma que o panorama politico-social, o nivel e o ritmo do desenvolvimento variam grandemente de um pais para outro. A administração de cada projeto de assistência técnica tem dimensões e caráter próprios e apresenta inúmeros problemas cruciais práticos.

Neste particular, poder-se-ia dizer que o fato de uma idéia, um principio ou um método ter nascido em determinada parte do mundo não é razão para aceitá-lo ou rejeitá-lo em outra parte. Entretanto, não tardará a erguer-se o brado: Aqui é diferente! 
O provável é que a eficiente administração de um projeto de assistência técnica dependa não apenas de técnicas e processos, mas também do conhecimento dos complexos fatôres históricos, culturais, sociais e outros, dentro da estrutura institucional do país hospedeiro. Entretanto, muito mais importante ainda é o uso que o encarregado do projeto faz dêsses conhecimentos. Sòmente através do levantamento e da análise realista da situação e das circunstâncias, condicionantes, de seu respeito pelos valôres culturais e de constante pesquisa, à qual dará grande dose de atenção, poderá o técnico encontrar o caminho através do qual dirigirá hàbilmente $\mathrm{o}$ projeto.

\section{II - O PROJETO}

A essência de um projeto de assistência técnica é prestar assistência ao pais hospedeiro, proporcionando-lhe os conhecimenmentos e a experiência de que necessita em determinado setor de seu interêsse, para o aproveitamento máximo de seus recursos naturais e humanos. E uma maneira consciente de resolver certos problemas ou séries de problemas técnicos especificos.

A razão de ser de um projeto de assistência é a contribuição positiva que o mesmo pode dar ao desenvolvimento do país anfitrião. Trata-se de um objetivo concreto. As tarefas envolvidas não são problemas abstratos, mas ligados a fatôres de localização, de conhecimentos, de pessoas e de tempo, dentro da perspectiva de todo o esfôrço do país interessado. Trata-se de conhecer não apenas as necessidades imediatas do aspecto funcional do projeto, mas também de saber como lançar as fundações para a construção de instituiçǒes capazes de enfrentar problemas futuros que venham a surgir.

\section{9) Caracteristicas}

As caracteristicas de um projeto de assistência técnica, de que estamos tratando, podem ser assim resumidas:

19) o projeto resulta de acôrdo entre uma organização internacional e uma nação soberana, à base de solicitação por esta formulada, na qual os objetivos, as responsabilidades e os têrmos são minuciosamente especificados;

$\left.2^{\circ}\right)$ o projeto é então formulado consoante as condições materiais, as necessidades e os recursos especificos do pais hospedeiro;

39) embora possua seus próprios objetivos, um projeto não constitui por si um fim. Espera-se que contribua para o desen- 
volvimento econômico-social equilibrado do pais beneficiário. Assim sendo, é um meio de alcançar metas mais amplas;

4) o projeto é de natureza consultiva. Suas principais funçóes são instituir, demonstrar, orientar, estimular processos autóctones, porém não tomar decisões nem administrar normas;

$\left.5^{\circ}\right)$ projeto é elemento temporário, pois que fixa a data da conclusão da tarefa do funcionário dêle encarregado;

$\left.6^{\circ}\right)$ por outro lado, o projeto tem, ao mesmo tempo, caráter permanente, uma vez que contém em seu bôjo um elemento de continuidade. Isso quer dizer que ao ser concluido o trabalho do encarregado do projeto,

a) um número suficiente de pessoas terão sido preparadas para dirigir e operar novos processos e resolver novos problemas e

b) um número suficiente de modificações terão sido introduzidas e terão sido criadas instituições nacionais permanentes, capazes de absorver futuros problemas e processos.

\section{9) Objetivos}

A maneira de analisar a administração de um projeto de assistência técnica deve basear-se na compreensão e no esclarecimento do projeto. Sòmente depois de colocados nas devidas perspectivas os objetivos do projeto e tornadas bem explicitas suas finalidades, estará o encarregado apto a tratar dos meios mais indicados para sua implementação. Ao tentar compreender os objetivos, é mister equacionar, clara e criteriosamente, as alternativas e os problemas envolvidos. Isso significa o conhecimento das interrelações de objetivos, meios e conteúdo sócio-econômicos, sempre que possivel obter êsses conhecimentos e, quando não, a consciência de sua ignorância. Não basta concordar em que determinado setor funcional do projeto merece atenção ou alta prioridade. Sem uma compreensão realista e explícita dos objetivos, pode haver confusão, desperdício de esfôrço e até mesmo atritos.

A imprecisão sôbre os objetivos do projeto pode levar a confusões, dúvidas e até controvérsias sôbre sua significação e suas implicações em têrmos das metas e dos meios de alcancá-las. Evidentemente, antes da formulação do projeto. haverá muita troca de idéias e informações. Mas, que dizer do "protagonista", isto é, do responsável pelo projeto ? Pode a administração de um projeto dessa natureza ser concebida sem levar em conta seu executor? $\mathrm{Na}$ verdade, não é possivel imaginar um encarregado de projeto de assistência técnica com a mentalidade de um filósofo do século XVIII. Os pressupostos e as atitudes do encarregado do projeto não são menos importantes que os objetivos. Por outro 
lado, pode acontecer que a definição do projeto seja demasiado rígida. A rigidez excessiva pode prejudicar o encarregado do projeto que, na respectiva administração, necessita manter sua perspectiva, flexibilidade, liberdade de decidir sôbre prioridades ou como concentrar-se no que fôr essencial. Como analista oriundo de outro país, poderá êle, por vêzes, discernir os elementos de uma situação melhor do que aquêles que estiverem empenhados na fixação dos objetivos.

Independentemente da rigidez ou da imprecisão dos objetivos do projeto, outra dificuldade existe. Trata-se da ajuda que o encarregado do projeto deve esperar da crganização internacional interessada, em matéria de orientação e esclarecimentos quanto às intenções e interpretações dos objetivos. Se, entretanto, não estiver muito segura acêrca dos objetivos e não tiver uma idéia bem clara das circunstâncias e do ambiente reinantes no país anfitrião, que possam influir em sua interpretação, a organizacão internacional não estará em condições de orientá-lo e esclarecê-lo. Com o tempo, poderá surgir alguma discordância. Nesse caso, o encarregado do projeto, que se encontra no próprio cenário da ação, estará em condições de discernir os elementos da situação e fornecer os esclarecimentos necessários. Contudo, convém acrescentar que, como raramente o encarregado do projeto pertence ao quadro permanente da organização internacional que o designou para a missão, não the cabe falar em nome da mesma.

Além disso, também é preciso não esquecer que os objetivos do projeto só poderão ser úteis se o país hospedeiro estiver bem convencido da importância do campo funcional do projeto e the der prioridade suficiente em seu programa de desenvolvimento. É isso que suscita a questão da interpretação e avaliação, isto é, das expectativas do país hospedeiro e de sua capacidade de utilizar o tipo de assistência procurado. Quando os objetivos refletem a política do país anfitrião ou as razões para levar avante o projeto, êsses objetivos podem proporcionar ao respectivo encarregado uma oportuna e objetiva compreensão.

\section{9) O panorama humano}

O pais hospedeiro, com sua organização especifica e quase sui generis das principais atividades, constitui o cenário dentro do qual se situam os problemas relativos à administração do projeto de assistência técnica. Convém acentuar que a administração eficiente de um projeto dêsse tipo exige de seu encarregado o conhecimento da estrutura cultural do país anfitrião e uma boa compreensão de suas crenças e convicções tais como expressas nos 
côdigos tradicionais de conduta, bem como do comportamento que, de acôrdo com os mesmos, se espera de cada indivíduo.

Todo pais tem sua História, suas tradições e seus valôres; sua técnica própria, sua estrutura de grupamentos populacionais, sua educação, seu nível de instrução, suas estatísticas de vida e saúde, seu próprio tipo de govêrno. Também tem seu amor-próprio, sua dignidade e seu senso de importância. Todos êsses elementos constituem um legado comum e são a base - em grande parte inconsciente - de crenças e compreensões comuns, que permitem a cada membro de uma determinada sociedade comunicar-se e viver em paz com os demais. Essa descrição, apesar de incompleta, faz lembrar que, embora seja comum a todos os homens a necessidade de um sistema de orientação e ligações, o conteúdo do sistema capaz de satisfazer a essa necessidade varia grandemente.

O homem sempre teve de enirentar certos problemas inevitáveis oriundos de situações criadas pela natureza. Em seus esforços para enfrentar êsses problemas, parece ter tentado quase tudo quanto é fisicamente possível. Embora, de um modo geral, tộdas as maneiras de viver pareçam semelhantes, as sociedades agem de diferentes maneiras e dão diferentes explicações, quase sui generis, sôbre o modo específico de resolver os respectivos problemas. As circunstâncias e as fôrças particulares que os levaram a adotar diferentes crenças e práticas parecem bem diferentes em cada sociedade.

Dentro dêsse panorama, a assistência técnica terá de ser recebida, assimilada e adaptada a cada circunstância especial. Entretanto, dificilmente é bem aceita a proposta de uma novidade ou de reforma. Nesse assunto é difícil calcular-se a receptividade de um país. Velhos hábitos não se transformam fàcilmente. Escudado na tradição, o povo resiste a qualquer mudança. Tendo em vista que os elementos que constituem uma sociedade tendem a formar um todo, consistente e integrado. é preciso enfrentar a possibilidade de que determinada prática venha a exercer influência duradoura e constituir-se em fonte de profunda satisfação e de segurança. A introdução de modificações ou de costumes estrangeiros pode criar condições mais inconvenientes que aquelas que se pretende sanar.

Não se deve interpretar essas observações no sentido de que nenhuma cultura possa ser modificada. A verdade é que pode. A cultura é suscetivel de modificação, desde que, para tanto, haja boa-vontade. Embora escravo da cultura de sua época e de sua terra, o homem não se escraviza passiva e completamente. Uma cbservação é particularmente significativa: as mudanças devem 
ser ordenadas e devem respeitar os valôres autênticos da sociedade. Convém recordar que a evolução humana baseia-se não apenas na adaptabilidade do homem, mas, também, em certas qualidades indestrutiveis de sua natureza, que o forçam a persistir na busca de condições mais ajustadas às suas necessidades.

\section{III — ADMINISTRAÇÃO}

Passando agora ao aspecto administrativo do problema, convém notar que "administração" não pode ser observada isoladamente como tal, mas apenas em suas manifestações específicas para alcançar as metas desejadas. Pode-se, perfeitamente, procurar os meios adequados, desde que êsses meios se ligam a determinados fins. Entretanto, como os principios do encarregado do projeto são mais ligados a valôres do que a técnicas, na administração de um projeto de assistência técnica entram fatôres delicados, bastante complicados. A natureza independente dêsses fatôres, modificando cada situação, torna um tanto complexa a administração de um projeto de assistência técnica. Temos assim um processo que começa com a auto-administração, até chegar à decisão, passando pelo ajustamento, o planejamento e a comunicação.

\section{1) Auto-administração}

A administração de um projeto de assistência técnica começa na pessoa de seu encarregado. O que importa, no caso, não é a consciência do individuo como ser humano complexo, de finalidades e valôres múltiplos (embora seja isso importante), mas o seu auto-domínio. Significa isso a luta para adaptar-se a um país estrangeiro, de cultura diferente, lidar com uma série de tensões diferentes daquelas a que estava habituado e introduzir mudanças básicas em seus hábitos, suas relações e suas fontes de satisfação. Significa, ainda, a tomada de consciência das próprias expectativas, daquilo que dêle outros esperam e a capacidade de equacionar tudo isso ao seu desejo egoísta de recompensa e reconhecimento. A vitória nessa luta exige muitos ajustamentos pessoais. É o que compreendemos por auto-administração, de importância primordial em vista do efeito que tem sôbre o resultado final do projeto. A auto-administração pode ajudar o encarregado do projeto a vencer os próprios caprichos, ter paciência quando tardam as respostas e as decisões, observar de visu as necessidades do país anfitrião, desenvolver uma sadia curiosidade e aprender e compreender, confrontando novas experiências com as anteriores. 


\section{9) Ajustamento}

Por ajustamento entendemos um espirito animador que proporcione no encarregado do projeto uma sensação de compromisso e de inspiração, frente aos objetivos visados. O ajustamento e de natureza qualitativa. Define em linhas gerais a direção a tomar em sua conduta prática. Significa impelir, ajustar e coordenar conscientemente todos os esforços para o desempenho das tarefas. O ajustamento não confere, porém, ao encarregado do projeto o dom de saber o que fazer em determinada situação. Capacita-o apenas a escolher e discernir, a julgar valôres, não arbitràriamente, mas consoante a opinião geral sôbre o que é certo. O preço da infringência a essa opinião é, não raro, o malôgro na realização das metas.

Pode acontecer que o encarregado do projeto se deixe empolgar pela tarefa a ponto de ficar destorcida sua capacidade de observação e deliberação. Pode manifestar-se nêle uma fixação quixotesca. E claro que a capacidade de ajustamento consciente depende da personalidade, do temperamento e da adaptabilidade do individuo. Chegando ao necessário ajustamento, o encarregado do projeto terá garantido sua competência independente.

\section{9) Know-how}

No âmago da administração de um projeto de assistência técnica situa-se o pressuposto de que seu encarregado conhece, na prática, o campo específico do projeto. Se assim não fôsse, por que seria enviado a ensinar ou ajudar a introduzir novas práticas e processos num país hospedeiro? Por verdadeira que pareça tal asserção, muitos concordam em que não basta a perícia técnica ou a eficiência. O êxito ou o malôgro não podem ser explicados simplesmente em têrmos técnicos ou à base do domínio de determinado assunto. Nada garante que as experiências de um pais se apliquem aos problemas de outros. Conforme frisamos antes, uma maneira de atuar que dê bons resultados num país pode não ser igualmente eficiente em outro panorama sócio-cultural; um princípio pode não ter o mesmo valor em todos os paises.

A alta especialização profissional sem os instrumentos adequados para compreender o povo e as instituições pode prejudicar a encarregado do projeto em sua adaptação ao nôvo meio. Não é fácil pedir-lhe reexaminar sua bagagem de conhecimentos profissionais e sua experiência, já integrados em sua pessoa, nem os requintes de técnicas e métodos a que está habituado. Não se the pode pedir, tampouco, que abandone seu bairrismo, os pres- 
supostos inconscientes, sob as lentes de outro conjunto de valôres e de outro modo de vida. É êsse investimento no campo funcional do projeto que, mais do que qualquer outro fator, explica os conflitos com que se depara um encarregado de projeto.

\section{4) Planejamento}

O planejamento é um requisito essencial, um elemento condicionante da eficiente administração de um projeto de assistência técnica. Mesmo com os objetivos fixados, sem planejamento o projeto pode transformar-se em simples aventura. De certo modo, o planejamento é um curso de ação mentalmente elaborado. Determina o que deve ser feito e em que seqüência. Leva em consideração as disponibilidades de mão-de-obra, as organizações institucionais, o tempo e outros fatôres que contribuem para a consecução dos objetivos. Implica também em certa dose de atividade autocorretiva, de acôrdo com as finalidades visadas, caso o plano em qualquer de suas fases pareça prejudicial ao êxito final.

Para planejar eficientemente, deve o encarregado do projeto ter acesso aos fatos controladores da situação. É importante realizar um levantamento preliminar completo das necessidades do país anfitrião, no setor abrangido pelo projeto. A dificuldade nesse ponto é obter informações.

Além disso, o encarregado do projeto precisa elaborar um programa. Não é possivel tratar de tudo ao mesmo tempo, nem adiar tudo de uma vez. Tendo sido determinada a data da conclusão do projeto, o estabelecimento de um programa possibilita ao respectivo encardegado determinar prioridades e concentrar esforços na realização, em tempo oportuno, de tudo quanto deva ser feito durante o prazo do projeto.

Ao mesmo tempo, é preciso que o encarregado não se deixe dominar pëlas pressões dos prazos e estude com calma o andamento do conjunto do projeto. Implica isso numa avaliação continua das providências tomadas no sentido de assegurar que as mesmas não prejudiquem a meta final. Entretanto, não poderá êle ser bem sucedido nesse particular, se procurar orientação para os problemas imediatos. Os problemas que enfrenta são parcialmente imediatos. A questão é ajudar o país anfitrião a atender a suas necessidades imediatas no setor funcional do projeto enquanto, ao mesmo tempo, lança as bases para fomentar o estabelecimento de instituições mais permanentes, destinadas a enfrentar problemas futuros. A atitude com que tratará dessa situação não deverá ser de descuidar-se dos problemas futuros, mas de equacioná-los com outras metas mais remotas e mais importantes. 


\section{5?) Comunicação}

O encarregado do projeto encontra-se numa atmosfera de interação diária, o que significa influir no comportamento de todos os interessados no setor funcional do projeto. Êstes podem auxiliar ou, pelo contrário, prejudicar a consecução dos objetivos visados. É o que coloca a comunicação no centro do palco de ação.

O significado de comunicação não é obter ou prestar informações nem tampouco fazer pronunciamentos ex cathedra. É um intercâmbio de idéias ponderáveis. É difícil, porém, conseguir uma compreensão autêntica entre as pessoas. Geralmente acredita-se ser a palavra um meio de comunicação. Em nossos hábitos diários de falar, convencemo nus de que usamos as palavras de modo correto. O ponto essencial da comunicação não está nas palavras ou nos sons que têm significação mas, sim, na reação que os mesmos provocam. Compreender o que se diz é conhecer a situação em que é dito. Na realidade, muito se pode comunicar através de atos, tanto como de palavras, mesmo sem nada fazer ou nada falar. Para que o ericarregado do projeto apreenda corretamente as comunicações deve êle perceber as fôrças culturais que as tornam inteligiveis.

\section{6) Processo decisótio}

O processo decisório contitui parte importante da adminis tração de um projeto de assistência técnica. Entretanto, o encarregado do projeto não tem podêres explícitos para tomar decisões. Não pode recorrer a "ordens" para alcançar os objetivos do projeto. Pode, isso sim, ajudar outro a dar ordens, o que é bem mais complicado do que dá-las diretamente. Sua capacidade de influir no comportamento de outras pessoas não depende de seus pronunciamentos, por mais esclarecidos que sejam. Neste particular, a consciência da decisão a ser tomada deve aliar-se ao conhecimento do processo decisório. $\mathrm{Na}$ verdade, o processo através do qual uma decisão é tomada não é menos importante que a decisão em si. Pode parecer desnecessário acentuar êsse ponto, mas o mesmo tem inúmeras ramificações.

Em primeiro lugar, não há outra alternativa senão partir do ponto em que se encontra. O encarregado do projeto começa com o conhecimento e as práticas no ponto em que as encontra. Para isso, faz-se necessária a participação e a colaboração dos interessados no setor funcional do projeto. Baseia-se isso na suposição de que, a adotar -se uma nova idéia apropriada ao caso, esta deverá resultar de todo um processo de formulação realista, 
nas condições do país hospedeiro e com a consciência das prováveis conseqüências das decisões que devam ser tomadas. $\mathrm{E}$, isso, o encarregado do projeto não pode prever com segurança. Demais, se a inovação resultar em mudança, melhor será que se baseie nos valôres existentes e na cooperação das pessoas sôbre as quais incidirá. Fatos objetivamente estabelecidos inevitàvelmente provocam questões de interpretação e julgamento as quais, por sua vez, dependem dos valôres sociais básicos, defendidos pelos interessados naquele determinado setor do projeto.

Pode-se concluir que se o encarregado conseguir receptividade na administração de um projeto de assistência técnica, será provàvelmente graças à sua capacidade de estabelecer comunicações, respeitando os valôres considerados importantes. Proporciona, assim, o meio através do qual se conjugam os valôres à situação dentro da qual a ação se realiza. Significa isso que, embora o encarregado do projeto não tenha podêres decisórios explicitos, sua autoridade decorre de seus conhecimentos e da aceitação que conquistar. Seus podêres sâo. pois, mais de sugestão que de comando. Êsses podêres não se fundamentam apenas em conhecimentos, mas - e principalmente - no aspecto qualitativo da comunicação.

\section{IV - INSTRUMENTOS E MÉTODOS}

A escolha ou a criação dos meios apropriados através dos quais se alcançam os objetivos constitui um dos principais problemas na administração de um projeto de assistência técnica. Seria preciso levar em conta todo um conjunto de fatôres interdependentes, bem como a delicada série de influências reciprocas entre o que se avalia e os meios de realização. Conforme acentuamos antes, o emprêgo de instrumentos e métodos adequados segundo a situação exige a compreensão clara e profunda dos objetivos, a fim de que fique evidente a relação entre os meios e os fins. Robinson Crusoe, quando resolveu deixar a ilha, construiu um barco de madeira, pesado demais para ser arrastado para o mar. É que estava tão empenhado no objetivo que nem refletiu bastante nos meios de alcançá-los.

O tópico a seguir analisa a instrução, a demonstração e o aconselhamento.

\section{1ค) Instrução}

O treinamento das pessoas ligadas ao setor funcional do projeto é instrumento fundamental e indispensável de qualquer projeto de assistência técnica. Âs vêzes, todo o projeto pode ser 
realizado como se fôsse uma experiência educacional. Convém lembrar que a instrução e o treinamento constituem as fôrças básicas no seio de uma sociedade capaz de progredir no campo social.

Pode-se apresentar fatos e ensinar técnicas, mas isso difìcilmente bastará. O homem é não apenas um animal que usa instrumentos, mas também um instrumento para alguma finalidade que não lhe seja própria. O homem é, por si, um fim: constantemente julga valôres e comporta-se em têrmos de preferências. Assim sendo, a instrução não é simplesmente uma questão de técn ca, mas destina-se a auxiliar os treinandos a assimilar $e$ praticar as leis de raciocinios válidos no tocante a determinado setor do projeto.

Em sua missão de instruir, o encarregado do projeto terá que partir do ponto em que se encontra o treinando, obtendo sua participação em cada nivel. Nessa tarefa ajudará o treinando a desenvolver a capacidade de utilizar as próprias habilitações e as próprios conhecimentos e, finalmente, encontrar soluções adequadas para os problemas, de acôrdo com o momento. Êsse método de tratar de conhecimentos e problemas é muito mais importante do que os problemas em si, por mais importantes que sejam. Exige, porém, por parte do treinando, uma verdadeira transformação, especialmente no tocante a certas atitudes que constituem obstáculcs a sua compreensão ou aceitação do que lhe é ensinado. O fato é que é difícil sobrepor novas atitudes às já existentes, a não ser que o indivíduo se convença realmente de seu valor.

\section{9) Demonstração}

A demonstração é o complemento da instrução. Na face da instrução o encarregado do projeto atua lenta e gradualmente. Através da demonstração, procura conseguir os resultados finais, por mais modestos que pareçam, abrindo assim a porta à real zação de suas potencialidades, caso venha a desenvolver novos métodos criadores. Eis ai a essência da demonstração: provar de modo concludente o que poderá ser feito, o que é possivel.

Em muitos casos a demonstração representa um método efetivo de ensino e ação. Representa uma experiência imediata. Pode ser melhor ou pior, ma's útil ou menos útil. Se visar apenas a provar que o encarregado do projeto é perito na realização de determinada tarefa, será menos útil e de efeito duvidoso. Ninguém aprende apenas olhando como outra pessoa, perita no as sunto, executa determinado trabalho. Será muito mais útil se visar a esclarecer os problemas envolvidos, identificar o processo 
de trabalho, suscitar perguntas e indicar os possiveis meios de resolver dificuldades. Poderá, então, a demonstração desenvolver nossos meios de criar nôvo ambiente, dentro do qual será possivel a implantação de novos hábitos. Poderá ser o comêço das realizações e proporc onar o aproveitamento mais efetivo dos limitados recursos existentes.

Ao fazer uma demonstração, é necessário escolher um tema ou setor suficientemente amplo para abranger tôdas as variantes. E preciso cuidado, porém, para não dar dimensões exageradas à demonstração, a fim de não criar dificuldades. Entretanto, certas variaçōes, tais como diferenças entre individuos ou fatôres mesológicos, não podem ser completamente controlados. Demais, é necessário evitar a tentação de realizar algo demasiado certo ou perfeito. A adaptação às condições peculiares de cada país é infinitamente mais importante do que o simples acêrto ou a perfeição do trabalho.

\section{9) Aconselhamento}

Conselho é coisa dificil de dar ou de receber. Cada ser humano tem seus propóstos e valôres e não seguirá cegamente o que considera ditado por outrem. Entretanto, na administração de um projeto de assistência técnica, o conselho é instrumento indispensável. O conselho torna-se eficiente pela maneira por que funciona. Embora refletindo, não raro, idéias e práticas acaso dominantes no momento, o conselho realista que forma a base da ação não pode ser pré-fabricado. Precisa ser descoberto conforme o caso.

$\mathrm{Na}$ formulação do conselhn não existe caminho direto para a certeza. Em primeiro lugar o encarregado do projeto necessita identificar os problemas envolvidos e descobrir o caminho certo de encará-los antes de tentar estudá-los. Convém lembrar que muitos problemas aparentemente insolúveis ficam sem solução até que se descubra a maneira certa de encará-los. Em seguida, precisa desenvolver várias hipóteses, suposições e linhas de ação, bem como construir uma estrutura sistemática de diferentes alternativas. A escolha certa entre estas pode ser complicada e problemática. Em que aspecto se modificaria a situação, caso fôsse aceita esta ou aquela alternativa? Quais as conseqüências práticas de cada alternativa? Se não fôr possivel encontrar a diferença é que as alternativas não têm sentido. Uma vez determinada a significação prática de cada alternativa proposta, o encarregado do projeto as apresenta a quem tenha podêres de decidir no setor funcional do projeto. explicando-lhe a importância $e$ as conseqüências de cada uma delas, escolha a que lhe 
pareça melhor e procura animá-lo a tomar as decisões necessârias.

Como base para a formulação do conselho, o encarregado do projeto precisa não sòmente conhecer o país e seus recursos mas, também, compreender e apreciar a significação de todos os fatôres envolvidos ou que venham a sê-lo. É mister ajustar seu parecer às exigências da situação, ao ritmo e às preferências dos padrões culturais do pais anfitrião. $O$ parecer não pode ficar distante da realidade a ponto de se tornar impraticável. Além disso, o encarregado do projeto precisa estar atento para não confundir parecer técnico com convicções pessoais. Não se justifica um conselho que seja aceito apenas porque o encarregado do projeto o formulou. Na verdade, a importância do autor é insignificante. É preciso dar as razões e estas devem ser sólidas. Evidentemente, conforme acentuamos, nenhum conselho ou parecer pode ignorar os valôres e os imperativos morais dos valôres tradicionais vigentes no pais em causa.

Mais um comentário caberá fazer. Ė preciso ser sensível à época e às mudanças básicas. Um parecer pode ràpidamente tornar-se obsoleto. Entre a formulação de um bom parecer $e$ sua tradução em instituição viva, há um intervalo não raro bastante largo. Nesse intervalo é provável que se modifique a natureza dos problemas. Sob êsse ponto-de-vista parece que até certo ponto tudo é flexivel. O parecer é um caso de aproximação e, assim sendo, não pode ser rígido. De outra forma, dependendo da extensão do intervalo, poderá referir-se a problemas já superados.

\section{9) O elemento pessoal}

Pelo exposto, parece evidente que grande parte do êxito de um projeto de assistência técnica pode depender do elemento pes. soal que o respectivo encarregado leva à sua administração. Entende-se por elemento pessoal uma qualidade que habilita o encarregado do projeto a esclarecer a situação, explicar problemas e suas causas e, bem assim, a capacidade de comunicar seus pensamentos sôbre as decisões a serem tomadas, respeitando sempre os valôres e as suscetibilidades. É um instrumento imponderável e importante, que supera todos os demais e cujo uso hábil pode facilitar ou retardar as transformaçôes de intenções e ação, com os respectivos resultados.

$\mathrm{Na}$ qualidade de estranho ao pais, o encarregado do projeto estará mais apto a discernir os elementos de uma situação do que os nela envolvidos; descobrir relações entre coisas aparentemente sem relação umas com as outras e servir de incentivador, 
particularmente quando a solução de um problema não é óbvio ou alcançável de pronto. Gradualmente criar-se-á em tôrno dêle uma atmosfera de confiança - confiança em seus conhecimentos e em sua capacidade, em sua dedicação, em sua compreensão, em sua adaptabilidade e sua visão.

\section{$\mathrm{V}$ - RELAÇÕES}

Num projeto de assistência técnica individual, o encarregado do projeto está sòzinho e, ao mesmo tempo, não está. Está só pelo fato de constituir por si uma entidade abrangendo o perito, o instrutor, o demonstrador, o consultor, o incentivador, o administrador... mas não é uma entidade à parte. $O$ isolamento total seria impossivel e sem sentido. Seus esforços ligam-se aos de outros no tocante a apoio, coordenação, transmissão do "know-how", tomada de decisões e ação. Evidentemente, a qualidade dessas relações pode afetar o resultado do projeto, pois as mesmas baseiam-se numa série de expectativas por parte do encarregado do projeto e de seu grau de realidade, inclusive a aceitação de certas responsabilidades.

Uma situação isenta de atritos é aquela em que tôdas as partes envolvidas sabem exatamente o que delas se espera e, por outro lado, o que cada uma espera da outra, comportando-se, conseqüentemente, de acôrdo com as expectativas. Tudo isso, porém, é hipotético e bem pouco provável. Talvez nem esteja na natureza da administração de um projeto de assistência técnica. Não são poucas as possibilidades de relações tensas, que chegam até a prejudicar o projeto.

\section{1\%) O "parceiro"}

A definição das relações entre o encarregado do projeto e o representante do govêrno contratante, bem como a responsabilidade que essas relações representam, constitui assunto dos mais delicados. Na realidade, o representante local é um alto funcionário do país hospedeiro, a quem cabe tomar decisões no setor funcional do projeto e com quem o encarregado do projeto se entende diretamente.

A natureza dessas relações tem uma forte orientação educional. O objetivo primordial é preparar um indivíduo a quem caberá ir além das operações rotineiras, embora sem perdê-las de vista, a fim de formular e dirigir as politicas gerais dentro da esfera funcional do projeto. Significa isso, em muitos casos, enfrentar problemas novos e complexos, que exigem o máximo de 
capacidade criadora. Nessas relações, embora sejam importantes as instruções e a orientação do encarregado do projeto, estas devem ir além e ajudar o funcionário nacional a fazer escolhas e avaliar efeitos a longo prazo.

Neste caso, ainda, vamos encontrar uma situação delicada. Por melhores que sejam as instruções e a orientação ministradas pelo encarregado do projeto, não poderão as mesmas aumentar a capacidade do funcionário para agir acertadamente quando necessário. Tampouco podem elas abranger todos os requisitos. Ninguém aproveita a experiência e os conhecimentos alheios, mesmo recebendo instruções das mais autorizadas. O que o funcionário apreende nada mais é do que as imagens que êle próprio cria acêrca do que ouve. E ninguém o condena por isso. Conhece sua terra e seus valôres, seu simbolismo, sua tradição, suas leis, seus recursos sua estrutura social, suas possibilidades, muito melhor do que o encarregado do projeto. Evidentemente, c encarregado do projeto terá de ajustar-se à personalidade do outro, a seu caráter e a sua experiência. Terá de sentir a situação, da mesma forma que êle.

Poder-se-ia concluir, que, a fim de que o funcionário possa aproveitar efetivamente as instruções do encarregado do projeto é preciso que as aceite como se suas fôssem. Poderá então agir de acôrdo com as sugestões, não por causa das instruções, mas por sua própria vontade. Nas relações entre ambos, o problema básico não é transpor as idéias e habilitações do encarregado do projeto, mas criá-las de nôvo como suas.

\section{2.) Outros projetos}

Outro grupo de problemas existe nas relações entre os responsáveis pelo projeto. Trata se da necessidade de coordenação dos esforços de assistência técnica no mesmo país hospedeiro. Cada projeto deve ligar-se às atividades e aos interêsses globais de desenvolvimento do país. De certo modo. todos os esforços. de desenvolvimento visam a objetivos simultâneos, complementares ou estritamente ligados.

Os vários projetos de assistência técnica podem apoiar e reforçar os demais, como sócios. Não é, porém, de estranhar que essa cooperação nem sempre se realize. O encarregado de um projeto pode preocupar-se com a árvore a seu cargo esquecendo a floresta. É possivel acontecer que um projeto corra paralelamente a outro ou o complemente e que, entretanto, os respectivos encarregados, embora se conheçam pessoalmente, nada saibam. 
do trabalho um do outro. Neste caso, cada um dêles talvez se concentre demasiado no que lhe pareça importante, compreensivel, com certo senso de urgência em seu projeto especifico, sem levar em consideração a necessidade de ajustá-lo ao esfôrço total de desenvolvimento e aos interêsses globais do pais. Seria ilusório esperar-se que o encarregado do projeto modifique suas atitudes. O estabelecimento de comunicações informais à base de relações pessoais pode dar melhores resultados.

\section{3:) Organizaçâo Internacional}

No estudo da organização as relações entre a sede e os serviços fora da sede apresentam dificuldades especiais. Não são fáceis tampouco as relaçốes entre o encarregado do projeto e a organização internacional que o custeia. O encarregado do projeto fora da sede tende a adquirir afeições e dedicações que o ligam ao país hospedeiro mais do que à organização patrocinadora. Mergulhado na realidade do país em que se encontra, passa a olhar como uma abstração a organização internacional, distante. $\mathrm{Na}$ realidade, a organização internacional é um misto de muitos individuos formando um microcosmo, cada um dos quais contribuindo com seu próprio modo de comportamento organizacional. Conforme o caso, podem essas pessoas incentivar ou entravar os esforços do encarregado do projeto, na consecução dos objetivos.

A situação, entretanto, pode não ser tão anômala quanto parece. Uma vez reconhecidas, as dificuldades serão levadas em consideração e, possivelmente, superadas. De modo especial, quando as expectativas do encarregado do projeto, bem como as da organização internacional baseiam-se em concepções realistas e são bem partilhadas, é possivel estabelecer uma base comum para chegar-se à compreensão da situação real do pais hospedeiro .

Convém notar que o encarregado do projeto, não raro preocupado com a conjuntura local, com a visão colorida pelos pressupostos e preconceitos que, inevitàvelmente, leva consigo, necessita da orientação da organização internacional, principalmente para a elucidação dos objetivos do projeto. Uma vez bem esclarecidos êsses objetivos, o encarregado do projeto pode receber uma orientação eficiente e segura. Depois, uma vez que é o responsável pelo projeto, é de esperar-se que tenha liberdade de ação, respondendo por seus atos e por suas omissões. Dêsse modo, quaisquer que sejam suas relações com a organização internacional interessada, estas não o dispensarão da autocrítica e da auto-administraçāo. 


\section{VI - OBTENÇÃo DE RESULTADOS}

Neste ponto será interessante considerar uma questão delicada, estreitamente ligada à situação global. Que efeitos terá o elemento administrativo na direção de um projeto de assistência técnica?

A fim de ter uma idéia clara da contribuição do elemento administrativo, o encarregado do projeto precisa considerar sua influência e sua utilidade prática. Como medida da prudência, deverá examinar cada providência que toma, do ponto-de-vista das respectivas conseqüências práticas. É essa a única significação do elemento administrativo. Nesta análise, entretanto, muitos obstáculos se levantam.

Em primeiro lugar, por mais competente que seja no setor funcional, o encarregado do projeto não pode prever com segurança os resultados gerais de sua linha de ação. A principal dificuldade, no caso, é determinar o terreno sôbre o qual se basearão as possiveis respostas, isso porque tôdas as realidades do país em causa, inclusive o reconhecimento de que os fatôres sociais e culturais, influem na conduta de um projeto técnico. Isso, porém, não nos deve fazer perder de vista a importância do elemento administração, mas, pelo contrário, lembrar sua importância. Sua influência na concretização dos resultados finais do projeto pode ser decisiva, mesmo que nenhum resultado prático ainda se evidencie.

Outra dificuldade existe, de outra natureza: a necessidade de encontrar soluções criadoras suscita a questão da necessidade de ação positiva por parte do país hospedeiro, no sentido da criação de instituições permanentes que se responsabilizem pelo aspecto funcional do projeto. Se assim não fôr, os métodos usados pelo encarregado do projeto, por melhor que sejam, serão ineficientes se não conseguirem estimular o país. É preciso, porém, fazer uma distinção. Pode o encarregado do projeto agir com responsabilidade e pode êle ser responsável por atos que não tenha liberdade de adotar ou de emitir? $\mathrm{E}$ os atos a que nos referimos aqui não são suas instruções, suas demonstrações ou seus conselhos em si, mas as decisões - as decisões acertadas que o país precisa tomar. Convém lembrar que decisões e mudanças podem ter grandes implicações e, além disso, que cabe ao elemento politico determinar o que se aplica e o que deve ser feito pela sociedade e para ela. Assim, os problemas não são apenas técnicos, mas também humanos, sociais e organizacionais. O reconhecimento dêsse fato atrai a atenção para as metas gerais, de preferência às questóes técnicas no terreno funcional do projeto. 
Este último comentário sugere a resposta à pergunta acima formulada. Partindo do princípio de que o encarregado do projeto tem uma obrigação para com o projeto e para com o país hospedeiro e tem visão suficiente para prever certas conseqüências dos métodos que emprega, poderá chegar a uma combinação de vários elementos os quais, por stia vez, poderão acarretar uma situação crítica, capaz de levar o país a proceder a uma mudança no terreno funcional do projeto. Não é fácil, porém, prever quando isso acontecerá. O equilibrio dos elementos varia grandemente, dependendo da conciliação de muitos objetivos, não raro contraditórios.

Essas observações não refletem qualquer regra geral. A administração de um projeto de assistência técnica não é simples e não pode enquadrar-se em generalidades. No processo de desenvolvimento do país hospedeiro, com ênfase em determinado setor de atividade, o projeto é apenas o comêço. O principal vem depois. 